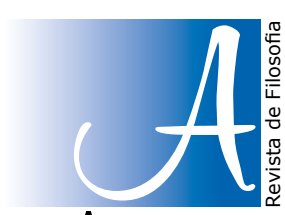

ARgumentos

Alfons C. Salellas Bosch ${ }^{*}$

\title{
Fragilidade da ação e realismo trágico em Arendt: um diálogo com Nietzsche
}

\author{
Action fragility of and tragic realism in Arendt: \\ a dialogue with Nietzsche
}

\section{RESUMO}

Existe um realismo trágico no plano de fundo de todo o pensamento arendtiano, que corresponde à sua forma de lidar com a fragilidade das questões práticas que se colocam entre os homens, sem renunciar - muito pelo contrário - à ação. Através da sua afinidade nietzschiana, busco evidenciar aquela que acredito ser a postura intelectual base de toda a reflexão político-filosófica de Hannah Arendt, que não é unicamente um subentendido, mas que aparece explícita em muitos momentos da sua produção.

Palavras chave: Arendt. Nietzsche. Frágil. Trágico.

\begin{abstract}
There is a tragic realism in the background of all Arendtian thinking, which corresponds to her way of dealing with the fragility of the practical issues that lie between men, without renouncing - quite the contrary - to action. Through her Nietzschean affinity, I seek to evidence what I believe to be the intellectual posture that is the basis of all the political-philosophical reflection of Hannah Arendt, which is not only an understatement but appears explicit in many moments of her work.
\end{abstract}

Keywords: Arendt. Nietzsche. Fragility. Tragic.

"A fragilidade dos assuntos humanos" é o título da seção 26, situada no capítulo V, do livro $A$ condição humana de Hannah Arendt. Esse título não é nem um

\footnotetext{
* Doutor em Filosofia (UFRGS). https://orcid.org/0000-0002-9682-0745
} 
aviso, nem uma capitulação. Um aviso para o controle de algo que precisa urgentemente de um fundamento ou uma capitulação diante de uma realidade que sai dos limites do controlável. Quando Arendt, ao abordar a ação, usa a palavra frágil - em qualquer uma das suas frases, em qualquer um dos seus livros -, sempre o faz não só como uma constatação, mas, principalmente, como uma sanção. Arendt foi sem dúvida alguma a primeira, e talvez a única, pensadora da política no século XX que assumiu jubilosamente a fragilidade do assunto que estava tratando, entendendo novamente por fragilidade não unicamente a falta de um fundamento que deveria buscar-se em algum tipo de além, como o perigo da certeza de haver encontrado um.

Nas páginas finais do primeiro capítulo do seu livro póstumo, $A$ vida do espírito, dedicado a "o pensar", Arendt (2009a, p. 234) depõe: "juntei-me claramente às fileiras daqueles que, já há algum tempo, vêm tentando desmontar a metafísica e a filosofia, com todas as suas categorias, do modo como as conhecemos, desde o seu começo, na Grécia, até hoje". Nesse sentido, Simona Forti frisa sobre o caráter "pós-heideggeriano" do pensamento político de Arendt que

sair da metafísica, ou melhor, reconhecer o esgotamento da força das suas categorias e de suas distinções, significa também para Arendt voltar a pensar nesse originário que a "filosofia profissional" esqueceu; logo significa reflexionar sem o amparo da theoria, rompendo com qualquer atitude contemplativa, sobre essa esfera dos assuntos humanos cuja contingência e "fragilidade" constitutivas são a condição de sua própria liberdade. É esse o modo arendtiano de romper com a metafísica; é esse o modo através do qual Arendt tenta ir além de Heidegger. (FORTI, 2001, p. 102, grifo meu). ${ }^{1}$

Se, tal como lembra Forti, o domínio dos assuntos humanos, e em particular a ação, são constitutivamente frágeis, por isso não se deve entender qualquer tipo de reconciliação, conformidade ou submissão a um destino inelutável. Acontece com o trágico da ação em Hannah Arendt o mesmo que com o absurdo da vida em Albert Camus: os dois são pontos de partida, não de chegada. As palavras que acompanham o trágico e o frágil na reflexão arendtiana são "coragem" e "responsabilidade", exemplificada nas ações livres e redentoras da promessa e do perdão, porque a responsabilidade, assim como a solidariedade, só pode conjugar-se com a liberdade, pois do contrário tratar-se-ia de coação.

Certamente, a obra desta autora está perpassada pela consciência da colonização de "o social" em todos os âmbitos da vida pública, pela consciência de que esse fator condiciona e míngua as possibilidades de efetivar o político com todo o seu potencial. Porém, isso não significa enterrar a política a benefício do marquetismo publicitário que se apoderou da "máquina dos partidos" (ARENDT, 2008b, p. 79), ou em favor de um economicismo tecnocrático sobre o qual ela já escrevera no frequentemente esquecido "Imperialismo", segundo capítulo de Origens do totalitarismo. Para Arendt, a política é rara, às vezes surge entre os ho-

\footnotetext{
"Salir de la metafísica, o mejor dicho, reconocer el agotamiento de la fuerza de sus categorías y de sus distinciones, significa también para Arendt volver a pensar en ese originario que la 'filosofía tradicional' ha olvidado; significa pues reflexionar, sin el amparo de la theoria, rompiendo con cualquier actitud contemplativa, sobre esa esfera de los asuntos humanos, cuya contingencia y 'fragilidad' constitutivas son la condición de su misma libertad. Es éste el modo arendtiano de romper con la metafísica; es éste el modo a través del cual Arendt intenta ir más allá de Heidegger" (FORTI, 2001, p. 102).
} 
mens, aparece nesse intraespaço, se estabelece como relação e "por conseguinte, não existe nenhuma substância política original" (ARENDT, 2004, p. 23, grifo meu). Em vista disso,

o espaço da aparência passa a existir sempre que os homens se reúnem na modalidade do discurso e da ação, e, portanto, precede toda e qualquer constituição formal do domínio público e as várias formas de governo, isto é, as várias formas possíveis de organização do domínio público. Sua peculiaridade reside no fato de que, ao contrário dos espaços que são a obra de nossas mãos, não sobrevive à efetividade do movimento que lhe deu origem, mas desaparece não só com a dispersão dos homens - como no caso de grandes catástrofes que destroem o corpo político de um povo -, mas também com o desaparecimento ou suspensão das próprias atividades. Onde quer que as pessoas se reúnam, esse espaço existe potencialmente, mas só potencialmente, não necessariamente nem para sempre. A ascensão e a decadência de civilizações, o declínio e o desaparecimento de impérios poderosos e de grandes culturas sem o concurso de catástrofes externas - e, na maioria das vezes, essas "causas" externas são precedidas por uma degenerescência interna que é um convite ao desastre -, devem-se a essa peculiaridade do domínio público que, pelo fato de repousar, em última instância, na ação e no discurso, jamais perde inteiramente seu caráter potencial. (ARENDT, 2014a, p. 249).

Como bem observa Jeffrey C. Isaac (1993, p. 536), baseado na verdade dos fatos, Arendt forjou sua sensibilidade e seu pensamento políticos na resistência antinazista na qual ela mesma participou. Essa experiência induziu Arendt a pensar e a escrever sobre o niilismo do mundo moderno, caraterizado pela quantidade ingente de pessoas sem teto, deslocadas e consideradas supérfluas - que é o termo que ela usava para significar descartáveis. Levou-a também a reflexionar sobre a guerra e a violência, sem esquecer que a invenção da bomba atômica marcou sua época com o perigo - ao qual já parecemos estar acostumados - de explodir o mundo, eliminar as espécies e pôr em risco a vida e o futuro do planeta. Essa experiência a persuadiu da importância da ameaça da hubris, a palavra grega que simboliza a desmedida causada pela ilimitabilidade da ação humana e que no século XX manifestou-se nas manobras de líderes totalitários, mas também dos revolucionários que esqueceram da contingência e dos limites da potência das ações dos homens, empenhando assim a força dos seus mais nobres impulsos. O corolário quase inevitável dessa agenda intelectual foi a importância que Arendt outorgou à coragem dos movimentos de resistência que historicamente lutam contra a opressão e a desumanização, e tentam construir espaços públicos provisórios - esses, como sabemos, são sempre provisórios - que permitam empoderar os cidadãos para conseguir estabelecer as bases do novo, os alicerces de outra esperança. O mesmo esforço de análise que Arendt realizou sobre os elementos que alteraram a ordem econômica, social e política, e que finalmente cristalizaram no fenômeno totalitário de domínio total, serviu-lhe para localizar e convocar na sua escrita aquelas pessoas, ações, instituições e tradições políticas que apresentaram, e continuam apresentando no mundo contemporâneo, oposição aos desígnios do terror absoluto. Iniciativas que visam ao sustento das qualidades exigidas a uma existência civil e cívica. Arendt (2008c, p. 9) escreveu no prefácio a Men in Dark Times que 
mesmo no tempo mais sombrio temos o direito de esperar alguma iluminação, e [...] tal iluminação pode bem provir, menos das teorias e conceitos, e mais da luz incerta, bruxuleante e frequentemente fraca que alguns homens e mulheres nas suas vidas e obras, farão brilhar em quase todas as circunstâncias e irradiarão pelo tempo que lhes foi dado na Terra.

Arendt não só pensou em G. E. Lessing, Rosa Luxemburg, Angelo Giuseppe Roncalli, Isak Dinesen ou Bertolt Brecht, alguns dos nomes que formam os perfis que a autora desenhou nesse livro singular, mas em todos os obstáculos legítimos, políticos e legais que evitam constantemente que o processo de expropriação do poder político da cidadania atinja o ponto em que a vida se tornaria completamente insuportável. Nesse sentido, Arendt afirmou em uma entrevista de 1970, publicada ao final do seu livro Crises da República, que em 1968 "a União Soviética marchou sobre a Tchecoslováquia, não por causa do novo 'modelo econômico', mas por causa das reformas políticas ligadas a ele." (ARENDT, 2008b, p. 187, grifo no original). Ou, expressando seu ponto de vista - isto é, seu julgamento político sem o qual o pensamento resta mudo - sobre as revoltas juvenis da década de 1960, a autora coloca o foco no prazer político redescoberto por uma geração que provocou o cambaleio nos passos dos representantes da ordem estabelecida. À pergunta de Adelbert Reif, a propósito do seu estudo Sobre a violência, em relação ao movimento estudantil nos países ocidentais, Arendt (2008b, p. 174175, grifos meus) dá uma longa resposta da qual extraio o seguinte recorte:

Menosprezando todas as diferenças nacionais, que naturalmente são muito grandes, e levando em conta somente que se trata de um movimento global - algo que nunca aconteceu nesta forma antes - e considerando (a menos de objetivos, opiniões e doutrinas) o que realmente diferencia esta geração em todos os países das gerações anteriores, então a primeira coisa que me surpreende é sua determinação para agir, sua alegria em agir, e certeza de poder mudar as coisas pelos seus próprios esforços. Isto, naturalmente, é expresso de forma diferente em cada país, conforme suas situações políticas e tradições históricas, o que em outras palavras significa conforme seus diferentes talentos políticos. [...] Esta geração descobriu o que o século dezoito chamou de "felicidade pública", o que significa que quando o homem toma parte na vida pública abre para si uma dimensão da experiência humana que de outra forma lhe ficaria fechada e que de uma certa maneira constitui parte da "felicidade" completa.

Como complemento a essa declaração genérica, e concentrada no contexto estritamente norte-americano - epítome de uma sociedade massificada na qual o apetite para a ação estaria supostamente erodido (HEATHER; STOLZ, 1979, p. 17) -, no ensaio Desobediência civil, de 1970, a autora salienta o poder dos indivíduos isolados reunidos para a ação,

pois os norte-americanos ainda encaram a associação como "o único meio que têm para agir", e com razão. Os últimos anos mostraram, com as manifestações de massa em Washington organizadas quase sempre na hora, até que ponto inesperado as velhas tradições ainda estão vivas. Esta consideração de Tocqueville quase poderia ter sido escrita hoje: "Tão logo alguns dos habitantes dos Estados Unidos tenham acolhido uma opinião ou um sentimento que desejam promover no mundo", ou tenham descoberto alguma falha que queiram corrigir, "procuram por 
assistência mútua e, uma vez que tenham se encontrado uns aos outros, associam-se. A partir deste instante, não são mais homens isolados mas um poder visto ao longe, cujas ações servem de exemplo e cuja linguagem é ouvida." (ARENDT, 2008b, 84-85, grifo no original).

Por velhas tradições cabe entender, por exemplo, a história sui generis dos judeus dinamarqueses, que Arendt refere no livro Eichmann em Jerusalém, no qual destaca o comportamento único do povo e do governo dinamarqueses, que a autora cita como exemplo do "enorme potencial de poder inerente à ação não violenta e à resistência a um oponente detentor de meios de violência vastamente superiores." (ARENDT, 2009b, p. 189-190). Podemos entender também o exemplo dos homens e das mulheres da Résistance française durante o nazismo, sobre a qual Arendt escreve no prefácio a Entre o passado e o futuro que

conforme eles mesmos o entenderam, parece ter consistido como que de duas partes interconectadas: tinham descoberto que aquele que "aderira à Resistência, encontrara a si mesmo", deixara de estar "à procura [de si mesmo] desgovernadamente e com manifesta insatisfação", não mais se suspeitara de "hipocrisia" e de ser "um ator da vida resmungão e desconfiado", podendo permitir-se "desnudar-se". Nessa nudez, despido de todas as máscaras tanto daquelas que a sociedade designa a seus membros como das que o indivíduo urde para si mesmo em suas reações psicológicas contra a sociedade, eles haviam sido, pela primeira vez em suas vidas, visitados por uma visão da liberdade; não, certamente, por terem reagido à tirania e a coisas piores - o que foi verdade para todo soldado dos Exércitos Aliados - mas por se haverem tornado "contestadores", por haverem assumido sobre seus próprios ombros a iniciativa e assim, sem sabê-lo ou mesmo percebê-lo, começado a criar entre si um espaço público onde a liberdade poderia aparecer. (ARENDT, 2007, p. 29-30, grifo meu).

Outros exemplos incluem a revolução americana na Filadélfia de 1776 ou a francesa do verão de 1789 em Paris, passando pela organização dos conselhos de bairro na revolução húngara de 1956 em Budapeste. Esse é o tesouro perdido da tradição revolucionária, cuja "herança não é precedida de nenhum testamento" nas belas, e amargas, palavras do poeta René Char -, que inspirou e modelou o conceito de ação política teorizado por Hannah Arendt ao longo de sua vida.

Isso tem diversas consequências. (1) Questiona fortemente a existência de dois modelos de ação e de domínio púbico no pensamento da autora, um agonístico e outro deliberativo (agon contra telos) como se depreenderia da leitura comparada de alguns exegetas da obra arendtiana. De fato, Maurizio Passerin d'Entrèves (1994, p. 10) faz a distinção entre um modelo de ação expressivo e outro comunicativo e, correlativamente, Seyla Benhabib (2003, p. 125) sugere dois modelos de política, um agonístico ou heroico e outro democrático ou associativo. Parece, não obstante, que esse binômio não forma parte do já abundante catálogo de distinções conceituais efetuadas por Arendt, mas que aquilo que a preocupava verdadeiramente era mostrar que "a política é o âmbito da responsabilidade, do aparecer ante os demais." (BIRULÉS, 2007, p. 92-93, grifo meu). Essa forma responsável de ver o domínio público e seus atores na teoria política arendtiana se ajusta à interpretação de Jeffrey C. Isaac (1993, p. 538), segundo a qual a ação política pensada por Arendt é uma ação por vezes confusa, mas sempre consequente, isto é, que produz resultados. Nem esse sujeito autônomo e autolegislador 
associado a Kant e às ilusões do liberalismo idealista, desacreditado na teoria por Nietzsche e Heidegger e na prática pelas derivas heterônomas do século XX; nem esse instrumentalismo transformador usado por fascistas, marxistas e liberais, baseado no cinismo da ligação entre meios e fins ("não se faz uma omelete sem quebrar ovos"2); "nem totalmente discursiva nem totalmente performativa, nem uma síntese dessas duas", a ação que Arendt pensa a partir dos dados empíricos é uma ação que traz consequências ${ }^{3}$. (2) Baseados na experiência e na história, os exemplos de resistência e de ação política revolucionária não só questionam como esfacelam e arruínam o comentário infeliz e desavisado de Isaiah Berlin, segundo o qual a escrita de Arendt seria uma "corrente de associação metafísica livre [...] sem nexos lógicos nem vínculos racionais e imaginativos" (JAHANBEGLOO, 1993, p. 112). (3) Coloca em evidência a falta de fundamento crítico para a afirmação de que a modernidade vista por Hannah Arendt só reveste conotações melancólicas e derrotistas, dizimando as leituras pós-modernas mais extremas. (4) A fragilidade da ação política teorizada por Arendt é responsável e consequente, logo jubilosamente trágica.

A certa altura do segundo volume, dedicado a "o querer", da sua última obra, $A$ vida do espírito, Arendt (2009a, p. 343) observa que "para uma filosofia de total alienação do mundo, há muita verdade na frase extraordinária com que Camus começou seu primeiro livro4: "Il n'y a qu'un problème philosophique vraiment sé-

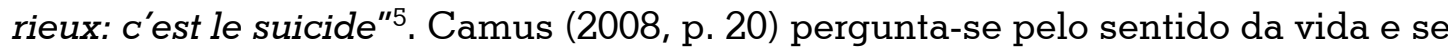
esta merece ser vivida, pois

um mundo que se pode explicar, mesmo com raciocínios errôneos, é um mundo familiar. Mas num universo repentinamente privado de ilusões e de luzes, pelo contrário, o homem se sente um estrangeiro. É um exílio sem solução, porque está privado das lembranças de uma pátria perdida ou da esperança de uma terra prometida. Esse divórcio entre o homem e sua vida, o ator e seu cenário é propriamente o sentimento do absurdo.

Para Camus, o reconhecimento do seu absurdo é o dado fundamental da vida humana, cuja falta de sentido, longe de ser desesperadora, é o símbolo incontestável de sua gratuidade. De modo que a vida não precisa de um sentido para ser vivida, mas ao contrário, cabe afirmar o sentido da vida na sua mesma falta de sentido. Contraditório,

o absurdo, por um lado, admite ser a vida o único bem necessário - rejeitando, assim, o suicídio e a esperança -, bem como, por outro, mantém o confronto desesperado entre a interrogação humana e o silêncio do mundo; afirmando, nesse sentido, a vida como díspar. (AMITRANO, 2014, p. 35).

\footnotetext{
2 "A 'sabedoria' dos provérbios realmente populares costuma ser o resultado cristalizado de uma longa linha de autêntica reflexão filosófica ou teológica." (ARENDT, 2008a, p. 301).

${ }^{3}$ Segundo Isaac, Arendt, ao reconhecer que toda ação tem consequências, que se encontra no mundo entre os homens, afetando e alterando o curso dos acontecimentos, coloca o acento no presente da ação e se protege dessa fé das ideologias modernas nas consequências futuras dos meios presentes. Trata-se de uma ação deliberativa, mas não puramente discursiva nem ingenuamente teleológica. É demonstrativa e frequentemente confusa, tal e como Arendt ainda segundo Isaac - observa em numerosas ocasiões. (ISAAC, 1993, p. 538).

${ }^{4}$ Le Mythe de Sisyphe [O mito de Sísifo].

5 "Só existe um problema filosófico realmente sério: o suicídio." (CAMUS, 2008, p. 17).
} 
Tanto em Camus como em Arendt, o absurdo e o trágico - sintomas de uma existência frágil - são formas respectivas de um pensamento afirmativo, mas não resignado e muito menos niilista. $O$ caso arendtiano de amor ao mundo é uma transposição do amor fati [amor à vida] nietzschiano. Assim, o trágico da ação humana não é que ela seja produtora do incerto (os homens não "produzem" ações). O pensamento trágico consiste em aprovar que essa ação seja lançada em um espaço e em um tempo sobre os quais não se tem o domínio - logo, ação trágica -, mas que sempre caem no âmbito, na esfera, da realidade imanente, longe e oposta a uma transcendência da qual o pensamento arendtiano está desprovido. $O$ dado fundamental que informa o caráter trágico do pensamento arendtiano se encontra já em Origens do totalitarismo, onde se lê:

O que as massas se recusam a compreender é a fortuidade de que a realidade é feita. [...] O acaso é o senhor supremo deste mundo e os seres humanos necessitam transformar constantemente as condições do caos e do acidente num padrão humano de relativa coerência. (ARENDT, 2011, p. 40l, grifo meu).

A mesma oposição que existe entre a necessidade e o acaso é a que há entre a justificação e a aprovação. Aprovar é negar que aquilo que existe deva ser justificado, posto que essa justificação é negadora em potência por não estar disposta a aprovar sem as condições da própria justificação. Daí o qualificativo de "jubiloso" desse modo trágico de pensar, pois não existe um sem o outro. Mas, nesse sentido, aprovar não significa comemorar a felicidade e a desgraça sem distinções e fazendo tábua rasa do sofrimento suportado por pessoas e grupos. O pensamento que afirma é aquele que não foge da realidade, que a reconhece na sua desmedida e na sua fragilidade, mas que também não se resigna a ela. Por isso podemos, e devemos, falar em responsabilidade ao escrever sobre Arendt, assumindo, com Wolfgang Heuer, que para essa pensadora,

a responsabilidade política não é uma categoria moral nem uma categoria republicana de um interesse prioritário acerca do bem comum, mas uma categoria existencial. Mesmo que Arendt confronte o espaço político com o acosmismo [rejeição do mundo], a ação política não é uma obrigação moral, como se fosse um sacrifício para o nascimento e manutenção do espaço político; ela é antes e acima de tudo uma atividade que nasce da espontaneidade e do deliciar-se na ação. Por isso, responsabilidade tem de ser compreendida como resposta existencial aos desafios do tempo, como o interesse pelo outro; como a abertura para mais além dos interesses privados, para os assuntos comuns num mundo comum, como uma ação que pressupõe a disposição para tolerar situações constrangedoras, porque somente a vida comum e pública parece, ao fim e ao cabo, valer a pena de ser vivida. (HEUER, 2007, p. 107).

Tomemos de novo em consideração a desobediência civil, essa forma de ação política, eminentemente moderna, que ela vinculou ao seu pensar. Trata-se de ações públicas, que devem ser organizadas e que pedem aos seus participantes coragem suficiente para enfrentar instituições oficiais com o risco de acabar presos. Essas ações são discursivas, mas não unicamente. Invocam símbolos, música, postura, denúncia, e colocam em destaque diferenças importantes de opinião (ISAAC, 1993, p. 538). Articulam uma mensagem e pedem apoio público para princípios de justiça ou para políticas públicas de um determinado tipo. 
Breve: a desobediência civil é agonística e deliberativa ao mesmo tempo, mas principalmente prática. E frágil, o que não desmerece sua solidez, pois a ação, mesmo se é desobediente - e precisamente por isso -, se insere num mundo de elementos interdependentes que já existia e que faz com que recomeçar de zero seja tão só uma ilusão vã.

Existe em Arendt, portanto, um reconhecimento inquestionável e inegociável do trágico, mas não uma acomodação cínica ao realismo político que, à maneira de Trasímaco em $A$ República de Platão (338c), iguala a justiça à conveniência do mais forte. Isso ficou demonstrado na sua defesa do princípio cosmopolita do "direito a ter direitos", que foi um chamado à comunidade internacional diante dos regimes que negavam direitos fundamentais a minorias e segmentos de sua população. Ou na sua repulsa de os julgamentos de Nuremberg incluírem os "crimes contra a humanidade" perpetrados pelos nazistas na velha categoria de crimes de guerra, pois isso levava implícita a total incompreensão por parte dos juízes da novidade com a qual se defrontavam (ARENDT, 2009c, p. 279). Na prática,

\begin{abstract}
foi quando o regime nazista declarou que o povo alemão não só não estava disposto a ter judeus na Alemanha, mas desejava fazer todo o povo judeu desaparecer da face da Terra que passou a existir o novo crime, o crime contra a humanidade - no sentido de "crime contra o status humano", ou contra a própria natureza da humanidade. A expulsão e o genocídio, embora sejam ambos crimes internacionais, devem ser distinguidos; o primeiro é crime contra as nações irmãs, enquanto o último é um ataque à diversidade humana enquanto tal, isto é, a uma caraterística do "status humano" sem a qual a simples palavra "humanidade" perde o sentido. (ARENDT, 2009c, p. 291).
\end{abstract}

Outros exemplos de defesa de políticas de resistência e preocupação pelas minorias já foram citados nestas mesmas páginas há pouco. Em qualquer caso, pensar em base a uma responsabilidade política não é o mesmo que repartir soluções ${ }^{6}$, visto que aquilo que constitui um pensamento trágico não é a afirmação do caráter inacessível das soluções, mas a afirmação do caráter absurdo da noção mesma de solução (ROSSET, 1976, p. 55).

Aquilo que há de irreversivelmente trágico na ação é que as consequências dos nossos atos desprendem-se das nossas intenções, se autonomizam e nos escapam, às vezes, por completo. Em consequência, a responsabilidade política torna-se problemática e entra em uma área na qual somos irresponsavelmente responsáveis das consequências não queridas dos nossos atos. Segundo Paul Ricoeur - que é consciente de suas afinidades - existe no entanto uma distinção entre o trágico e o frágil. Distinção que não levarei em consideração, mas que é interessante mencioná-la. Para Ricoeur (2003, p. 128), aquilo que diferencia o trágico do frágil é sua relação com a responsabilidade. O trágico evoca uma situação na qual o homem toma consciência de um destino ou de uma fatalidade. Esta é uma concepção determinista do trágico decorrente do teatro grego que, mesmo tendo alguns pontos em comum já assinalados com Arendt, não é a que aqui nos interessa. Já o frágil, de acordo com Ricoeur, apela à ação, em virtude de um laço

\footnotetext{
${ }^{6}$ Quando insisto em que a filosofia de Hannah Arendt não é normativa, quero dizer que não se assemelha a nenhum código de circulação para chegar a algum porto determinado. Arendt, nesse sentido, está longe de um Habermas ou de um Rawls.
} 
intrínseco com a ideia de responsabilidade. Por isso minha insistência na irresignação arendtiana diante da lúcida consciência da fragilidade e da incerteza da política. Não obstante, penso que o trágico, ou o ponto de vista trágico sobre a política e os assuntos humanos em geral, tem um sentido mais amplo e filosófico que aquele que se restringe à especificidade de um género literário concreto. Por isso, a diferença de Ricoeur, considero que o trágico e o frágil, a tragicidade e a fragilidade da política em termos gerais, e da ação em particular, são dois aspectos do mesmo assunto. Um é indissociável do outro e aos dois cabe a mesma reflexão sobre os limites e a dúvida sobre a responsabilidade abrangente dos nossos atos no espaço público. Quando Arendt (2014a, p. 304) escreve que "a incapacidade do homem para confiar em si mesmo e para ter fé absoluta em si próprio (o que é a mesma coisa) é o preço que os seres humanos pagam pela liberdade" está pondo de manifesto a fragilidade constitutiva da liberdade humana, que é o enfoque que atravessa todo o seu pensamento político-filosófico. Quando seguidamente a autora expressa que a impossibilidade dos homens

\begin{abstract}
de permanecerem como senhores únicos do que fazem, de conhecerem as consequências de seus atos e de confiarem no futuro é o preço que pagam pela pluralidade e pela realidade, pela alegria de coabitarem com outros em um mundo cuja realidade é assegurada a cada um pela presença de todos,
\end{abstract}

Arendt manifesta a ótica trágica, nunca abandonada, que penetra a totalidade de sua reflexão ao longo dos anos. Em Arendt há essa visão, que sempre poderá ser complementada (por exemplo, pelas interpretações performativa ou deliberativa apontadas nestas páginas), mas nunca superada, como a única eficaz na consideração corajosa da liberdade, ou seja, aquela que não esconde nem tem a pretensão de solucionar seu caráter aberto e imprevisível. Sem ignorar a necessidade, a perspectiva trágica é a única que não admite sua coerção e, por isso, mesmo que admita a possibilidade da desesperança, seguida de um quietismo conformista, advoga igualmente por uma ação firme e alegre ao mesmo tempo que lúcida e desiludida. Nesta segunda concepção, a ressonância de Nietzsche em Arendt reconhece a dimensão insubmissa e criadora dos homens, de modo que aqui, e em contraste com a percepção determinista do teatro grego, o único que pode ser chamado de destino humano é sua liberdade. O problema que se coloca aqui, tentando a sorte, é atuar ou não atuar, uma vez reconhecido o fato de que só na ação, por imprevisível, ilimitada e irreversível, existe conflito trágico, pois como já observara Cioran (1997, p. 87), o trágico dos assuntos humanos se evapora quando vistos de cima, fora do tempo.

Nietzsche usava com frequência o que ele chamava de "meu pessimismo" para distingui-lo daqueles que o precederam, mas que, no entanto, ajudaram a forjar sua concepção. Conhecidos são seus débitos com os pré-socráticos, os quais, ele pensava, possuíam uma noção afiada da natureza caótica e desordenada do mundo, e do compromisso com Schopenhauer, do qual ele, depois de um primeiro e intenso momento de admiração, afastou-se para sempre. Somadas essas dívidas às menções que ele faz ao longo de sua obra ao pessimismo do poeta italiano Giacomo Leopardi ${ }^{7}$, compreendemos que a visão da vida e do

${ }^{7} \mathrm{Na}$ Segunda consideração intempestiva, Nietzsche cita o poeta: "Nada vive que digno fosse de tuas emoções / e 
mundo que o filósofo exteriorizava vinha de longe. Finalmente, a alternativa nietzschiana chegou no aforismo 370 de $A$ gaia ciência, no qual Nietzsche começa a escrever sobre um pessimismo que ele chama de dionisíaco, principalmente por oposição a um "pessimismo romântico" cujos expoentes típicos seriam, segundo ele, a música de Wagner e a filosofia da vontade de Schopenhauer. Nietzsche não faz questão de apropriar-se do termo "pessimismo dionisíaco" para nomear sua filosofia, mas o emprega como tentativa de desenhar uma possível filosofia futura. Todavia, e talvez entrando em franca contradição, desse pessimismo, que Nietzsche diz querer distinguir da noção popular mais estendida, "um pessimismo inteiramente outro", ele afirma: "tal visão e intuição pertence a mim, é inseparavelmente minha, meu proprium e ipissimum [quintessência]." (NIETZSCHE, 2001, p. 273). Comumente, o pessimista é apresentado como alguém que pensa e leva a vida como um fardo insuportável. Nietzsche inverte esta assunção e ostenta uma visão do pessimista como quem, no mínimo e de início, não espera nada da vida e portanto resta aberto às surpresas que o otimista só percebe como acidentes perturbadores de uma linha de progresso preestabelecida. "É tempo do grande meio-dia, da mais terrível iluminação: minha espécie de pessimismo: - grande ponto de partida." (NIETZSCHE, 2008a, p. 92), escreve Nietzsche nos fragmentos póstumos. De todo modo, já no importante ensaio intitulado "Tentativa de autocrítica", que principia a terceira edição, datada em 1886, de sua primeira grande obra, $O$ nascimento da tragédia, Nietzsche desafia ao seu leitor e pergunta:

Será o pessimismo necessariamente o signo do declínio, da ruína, do fracasso, dos instintos cansados e debilitados - como ele o foi entre os indianos, como ele o é, segundo todas as aparências, entre nós, homens e europeus "modernos"? Há um pessimismo da fortitude? [...] E de outra parte: aquilo de que a tragédia morreu, o socratismo da moral, a dialética, a suficiência e a serenojovialidade do homem teórico - como? Não poderia ser esse socratismo um signo de declínio, do cansaço, da doença, de instintos que se dissolvem anárquicos? [...] É a cientificidade talvez apenas um temor e uma escapatória ante o pessimismo? Uma sutil-legítima defesa contra - a verdade? (NIETZSCHE, 1999, p. 2, grifos no original).

Para Nietzsche, a cientificidade e o "otimismo socrático" são intelectualismos, imposturas intelectuais ocupadas em fazer desaparecer, de modo que não se perceba, a fragilidade imanente da vida dos homens na Terra. (Crítica semelhante existe em Arendt, aplicada à tradição filosófica de pensamento político sobre o domínio dos assuntos humanos.) Nietzsche outorga ao pessimista dionisíaco uma mente aberta que lhe confere a prudência e a equanimidade difíceis de encontrar no otimista inveterado, que sofre por causa dos desapontamentos de um mundo caótico que não segue a linha ascendente que ele lhe atribuía, e que tampouco saberia dizer exatamente para onde o encaminhava. Assim as coisas, se o pessimista é percebido popularmente como um triste e resignado ao modo romântico e schopenhaueriano, o dionisíaco que descreve e defende Nietzsche é um pessimista espontâneo que valoriza o que lhe é dado, a vida e o mundo que recebe, precisamente por causa de não albergar grandes expectativas ante o fu-

nenhum suspiro merece a terra. / Dor e tédio são nosso ser e sórdido é o mundo - nada além disto. / Aquieta-te" (NIETZSCHE, 2003, p. 16). 
turo. De forma que esse pessimismo dionisíaco não se deixa igualar ao cinismo, ao niilismo nem ao conformismo:

Não! - exclama Nietzsche no Nascimento da tragédia - Vós deveríeis aprender primeiro a arte do consolo deste lado de cá - vós deveríeis aprender a rir, meus jovens amigos, se todavia quereis continuar sendo completamente pessimistas; talvez em consequência disso, como ridentes mandeis um dia ao diabo toda a "consoladoria" metafísica - e a metafísica em primeiro lugar. (NIETZSCHE, 1999, p. 23, grifo no original).

O que Nietzsche se propõe ao reivindicar esse caráter dionisíaco para esse pessimismo, que em outros momentos ele chama de pessimismo da fortitude, é dar a entender que o pessimismo não leva necessariamente à apatia, ao estoicismo ou a uma resignação taciturna, mas a uma atividade vivaz, porém desenganada.

Schopenhauer, um lugar de sofrimento contínuo cujo final não se avista. Não obstante, o autor do Zaratustra decidiu tomar uma rua diferente para lidar com esse peso. Com Nietzsche aprendemos que a existência não vale por ela estar avançando através de uma linha imaginária de progresso sustenido; nem por seguir as diretrizes de um deus com o qual ao final da história deveríamos nos encontrar; nem por ser o lugar de castigo e expiação dos nossos erros, das nossas carências ou das nossas faltas. Para ele, a ideia mesma de uma justificação metafísica, isso que ele chama de "consoladoria", não faz nenhum sentido. O que vale para Nietzsche é essa transformação constante, essa contínua reaparição da novidade, que é a consequência, o produto próprio, junto com a decadência e a morte, da existência no tempo.

O antigo hábito, porém, de em todo acontecimento pensar em fins e de, para o mundo, pensar em um Deus condutor e criador é tão poderoso que, ao pensador, custa esforço não pensar para si próprio a falta de finalidade do mundo, por sua vez, como uma intenção. Nessa inspiração - [...] - haverão de incorrer todos aqueles que gostariam de decretar para o mundo a capacidade da eterna novidade, isto é, gostariam de decretar tal coisa com relação a uma força final, determinada, imutavelmente da mesma grandeza, tal como é "o mundo" - a capacidade maravilhosa da infinita reconfiguração de suas formas e situações. (NIETZSCHE, 2008a, p. 509, grifos no original).

Sem desprezar a via aristotélica à perspectiva trágica da ética e da política, desenvolvida por autores como Pierre Aubenque, Jacques Taminiaux, Martha Nussbaum, Paul Ricoeur ou Robert C. Pirro, alguns deles com livros e textos que comentam e iluminam a obra de Hannah Arendt, e com forte arraigo na tragédia como género privilegiado da literatura grega ${ }^{8}$; sem desprezar tampouco a própria autora, que em diversos lugares de sua obra cita, comenta e usa a tragédia grega como apoio para os seus argumentos, penso que há outra via, a via nietzschiana, para explicar o caráter trágico do pensamento arendtiano como assentimento da fragilidade intrínseca dos assuntos humanos. Acredito que a obra de Arendt está perpassada por um sensível e notório espírito nietzschiano - independentemente

\footnotetext{
${ }^{8}$ María Pía Lara observa com pertinência que "as tragédias tematizaram a compreensão histórica do que significa a fragilidade humana. Por isso Aristóteles cria que essa complexidade só poderia se mostrar através de recursos literários do gênero da tragédia, isto é, de uma história representada por meio da ação" (LARA, 2009, p. 61).
} 
da quantidade de vezes que ela tenha citado Friedrich Nietzsche de forma direta - e que este se expressa nela, a título de exemplo, através desta eterna novidade que para a autora representa a natalidade como atributo especial da condição humana. O nascimento de cada ser humano representa um novo começo e cada ação que ele empreende uma série de novas possibilidades. Portanto, está nos homens essa capacidade maravilhosa de infinita reconfiguração do mundo da qual falava Nietzsche e que na linguagem de Arendt se torna "milagre". Se a mortalidade influi e marca nossas vidas não só no momento de nossa morte, a natalidade faz o mesmo muito para além do dia em que chegamos ao mundo. De resto, nada de tudo aquilo que os homens fazem durará para sempre, mas o fato de sua novidade pode ser apreciado pelo que ela é e representa, além das consequências que possa gerar.

Visto desde fora do seu próprio linguajar, o pessimismo dionisíaco e o pessimismo da fortitude que Nietzsche se atribui, ou seja, esse aspecto concreto da sua filosofia, pode ser tranquilamente categorizado como um realismo trágico. Gostaria de sugerir que no decurso de toda a obra de pensamento político de Hannah Arendt subjaz esse realismo trágico de corte nietzschiano. Essa categoria não pode ser substituída pelos traços performativo e discursivo - nem por qualquer outro que se lhe possa adjudicar de modo plausível - que coabitam na obra da pensadora, mas tampouco poderia ser ela quem os substitua. Existe um realismo trágico no plano de fundo de toda a reflexão arendtiana, que corresponde à sua forma de lidar com a fragilidade das questões práticas que se colocam entre os homens sem renunciar - muito pelo contrário - à ação. Minha pretensão não é domesticar, de novo, o livre pensamento desta autora. Não quero encaixá-lo em outro "ismo" simplificador. Ficaria satisfeito se o leitor admitisse comigo aquela que acredito ser a postura intelectual base de toda a reflexão político-filosófica de Arendt, que não é unicamente um subentendido, mas que aparece explícita em muitos momentos da sua produção. Como judia, Arendt viu seu mundo quebrar por causa dos excessos de um regime totalitário que desejava a eliminação do seu povo. Foi testemunha de primeira mão e sofreu os perigos e a desmesura da ação empreendida pelos homens. Teve sorte em sobreviver. Não é preciso insistir muito mais sobre isso. O que restou para sempre nela foi uma sabedoria prática, uma prudência. Arendt é uma pensadora da ação. A ação humana acontece no tempo e o nega, a ação é kairós, oportunidade demolidora da sucessão cronológica. (SAVATER, 1981, p. 59). Entretanto, dever-se-ia apreciar também em Arendt uma filosofia dos limites que não se permite glorificar ingenuamente a faculdade humana de agir. Nesse justo sentido, me parece decisivo lembrar sempre aquilo que Arendt explicou ao historiador Joachim Fest em 1964: a ação conjunta - ir junto com o resto [going along with the rest] - é produtora de poder. Todavia, esse sentimento de poder que surge da ação combinada não é mau, é um sentimento humano geral. "Mas tampouco é bom. É simplesmente neutral." (ARENDT, 2013, p. $43)^{9}$. Para Arendt o poder é apenas um fenômeno humano que produz prazer naqueles que o experimentam. Mas há também uma forma perversa da ação, reconhecida pela autora, como um mero funcionar [the really perverse form of acting is

\footnotetext{
9 "Eichmann was outrageously stupid". In: The Last Interview and Other Conversations.
} 
functioning], o comportamento rudimentar de quem segue decisões alheias. $\mathrm{E}$ nessa forma de agir, alerta Arendt, também existe prazer. Adolf Eichmann, um dos máximos responsáveis da "solução final", e o único protagonista real do conhecido livro da autora, "queria ir junto com o resto. Ele queria dizer 'nós', e indo-junto-com-o-resto e querendo-dizer-nós dessa maneira foi suficiente para cometer o maior de todos os crimes possíveis" (idem) ${ }^{10}$.

O realismo trágico de Arendt está na contramão da maioria de filosofias políticas do século XX e atuais que, mesmo considerando-se pós-metafísicas, refugiam-se num otimismo mal dissimulado, que participa da metafísica enquanto repulsa contra um mundo que faz sofrer. Equivoca-se aquele que pensa que o ressentimento na modernidade é propriedade exclusiva de Schopenhauer. O mito do progresso, abraçado à esquerda e à direita, e do qual estamos longe de estarmos livres, continua a precipitar para um futuro indefinido aquilo que as filosofias metafísicas projetavam para um plano transcendente. Nesse sentido, o que resulta catártico da filosofia da fragilidade arendtiana é precisamente o reconhecimento da nossa falta de poder absoluto, o desembaraço da ilusão deturpadora de nós sermos os mestres perfeitos dos nossos dias, empresa para a qual precisa-se de justificações de todo tipo, inclusive as mais temíveis. Livre da idolatria do amanhã, Arendt tomou boa nota do romance visionário de Dostoiévski, Os demônios, do qual escreveu uma resenha da qual extraio aquilo que para ela é seu argumento teórico:

Se o Deus ao qual o homem deve obediência desaparece, o homem segue existindo, disposto para ser um criado, só que em vez de servir a Deus agora é servo de suas ideias; já não é uma propriedade de Deus, mas agora está possuído pelas ideias, e estas atuam como se fossem demônios. As ideias não são algo que se possua, [senão que] são as ideias as que possuem. (ARENDT, 2014b, p. 169).

Quando Arendt afirma em Origens... que "o acaso é o senhor supremo deste mundo" (ARENDT, 201la, p. 401) está, entre outras coisas, denunciando o embuste daqueles que acreditam, aberta ou clandestinamente, que o mundo pode ser "caçado" por ideias postas em prática, seja quando e da maneira que for. Mas nessas circunstâncias, pergunta Nietzsche, "quais mostrar-se-ão os mais fortes?" A resposta do filósofo agradaria Arendt:

Os mais moderados, aqueles que não têm necessidade de princípios de crença extremos, aqueles que não só reconhecem uma boa parte de acaso, de absurdo, mas antes a amam, aqueles que podem pensar o homem com uma significativa moderação do seu valor, sem por isso se apequenarem e se debilitarem. (NIETZSCHE, 2008a, p. 55, grifos no original).

Com independência de se é boa ou é má, a ação para Arendt é sempre um "nós", não um "eu". No segundo caso, um ator único e solitário poderia prever aquilo que deveria acontecer como consequência dos seus atos, mas no primeiro, que é aquele que Arendt chama propriamente de ação, a contingência tem um papel decisivo e incontestável. Ninguém sabe o que acontecerá simplesmente porque em boa medida depende de uma grande quantidade de variáveis, ou seja,

\footnotetext{
10 "He wanted to go along with the rest. He wanted to say 'we', and going-along-with-the-rest and wanting-to-say-we like this were quite enough to make the greatest of all crimes possible."
} 
do simples acaso. (ARENDT, 2013, p. 118) ${ }^{11}$. Abro um pouco mais o foco para apreciar melhor a dimensão do assunto: o caráter limitado, transitório e contingente de cada ato e de cada escolha, tomados no contexto da multidão de outros atos e de outras escolhas (pensamentos, modificações e retificações, feitas por nós e por outros), que transformaram, transformam e continuarão a transformar cidades, países, sociedades e continentes inteiros, outorgam ao domínio público e a ação conjunta dos homens uma fragilidade e uma mutabilidade que não só acomoda como aprova e estima a incerteza. Essas são as condições de possibilidade para a permanente e interminável construção de um "mundo" plural, o único que é digno de levar esse nome. A isso Hannah Arendt disse "Sim".

Situada entre "os que acreditam na ruína final e os que se entregam ao otimismo temerário", Arendt escreveu no prefácio à primeira edição de Origens do totalitarismo palavras que representam um farol que nos guia para a interpretação do resto da sua obra: "Este livro foi escrito como mescla do otimismo temerário e do desespero temerário", pois, "compreender significa, em suma, encarar a realidade sem preconceitos e com atenção, e resistir a ela - qualquer que seja." (ARENDT, 201 la, p. 12). O realismo arendtiano não consiste em outra coisa, mas penso que as três últimas citações são tomadas comumente pelo intérprete como retórica de prólogo para logo encarar o texto da autora com lentes que podem chegar a distorcer essa sólida declaração de intenções, que Arendt nunca abandonou.

\section{Referências}

AMITRANO, Georgia. Albert Camus: um pensador em tempos sombrios. Uberlândia: EDUFU, 2014.

ARENDT, Hannah. O que é política?. Rio de Janeiro: Bertrand Brasil, 2004.

. Entre o passado e o futuro. São Paulo: Perspectiva, 2007.

. Compreender: formação, exílio e totalitarismo (ensaios 1930-1954). São

Paulo: Companhia das Letras, 2008a.

. Crises da República. São Paulo: Perspectiva, 2008b.

. Homens em tempos sombrios. São Paulo: Companhia das Letras, 2008c.

. A vida do espírito. Rio de Janeiro: Civilização Brasileira, 2009a.

. A promessa da política. Rio de Janeiro: Difel, 2009b.

. Eichmann em Jerusalém. São Paulo: Companhia das Letras, 2009c.

. Origens do totalitarismo. São Paulo: Companhia das Letras, 2011.

. The Last Interview and other Conversations. New York: Melville House, 2013.

. A condição humana. Rio de Janeiro: Forense Universitária, 2014a.

- Más allá de la filosofía: escritos sobre cultura, arte y literatura. Ed. Fina Birulés y Àngela Lorena Fuster. Madrid: Trotta, 2014b.

\footnotetext{
11 "Nobody knows what is going to happen simply because so much depends on an enormous amount of variables; in other words, on simple hazard." Arendt em conversação com Roger Errera, "The last interview". In: The Last Interview and Other Conversations.
} 
BENHABIB, Seyla. The reluctant modernism of Hannah Arendt. Lanham, Md: Rowman \& Littlefield, 2003.

BIRULÉS, Fina. Una herencia sin testamento: Hannah Arendt. Barcelona: Herder, 2007.

CAMUS, Albert. O mito de Sísifo. Rio de Janeiro: Record, 2008.

CIORAN, E. M. Cahiers, 1957-1972. Paris: Gallimard, 1997.

FORTI, Simona. Vida del espíritu y tiempo de la polis: Hannah Arendt entre filosofía y política. Madrid: Cátedra, 2001.

HEATHER, G.; STOLZ, M. Hannah Arendt and the Problem of Critical Theory. The Journal of Politics, n. 41, p. 2-22, 1979.

HEUER, Wolfgang. Amizade política pelo cuidado com o mundo: sobre política e responsabilidade na obra de Hannah Arendt. História: Questões \& Debates. Curitiba: Ed. da UFPR, n. 46, p. 91-109, 2007.

ISAAC, Jeffrey C. Situating Hannah Arendt on Action and Politics. Political Theory, v. 21, n. 3, p. 534-540, Aug. 1993.

JAHANBEGLOO, Ramin. Isaiah Berlin en diálogo con Ramin Jahanbegloo. Madrid: Anaya \& Mario Muchnik, 1993.

LARA, María Pía. Narrar el mal: una teoría posmetafísica del juicio reflexionante. Barcelona: Geidsa, 2009.

NIETZSCHE, Friedrich. O nascimento da tragédia. São Paulo: Companhia das Letras, 1999.

. A gaia ciência. São Paulo: Companhia das Letras, 2001.

. Segunda consideração intempestiva: da utilidade e desvantagem da história para a vida. Rio de Janeiro: Relume Dumará, 2003.

. A vontade de poder. Rio de Janeiro: Contraponto, 2008a.

. Além do bem e do mal. São Paulo: Companhia das Letras, 2008b.

PASSERIN D'ENTRÈVES, Maurizio. The Political Philosophy of Hannah Arendt. New York: Routledge, 1994.

RICOEUR, Paul. Fragilité et responsabilité. Autres Temps. Cahiers d'éthique sociale et politique, n. 76-77, p. 127-141, 2003.

ROSSET, Clément. Lógica de lo peor. Barcelona: Barral, 1976.

SAVATER, Fernando. La tarea del héroe. Madrid: Taurus, 1981.

\section{Sobre o autor}

Alfons C. Salellas Bosch

Doutor em Filosofia pela UFRGS. E-mail: asalellas@hotmail.com

Recebido em 12/12/2018

Aprovado em 09/07/2019

\section{Como referenciar esse artigo}

BOSCH, Alfons C. Salellas. Fragilidade da ação e realismo trágico em Arendt: um diálogo com Nietzsche. Argumentos: Revista de Filosofia. Fortaleza, ano 11, n. 22, p. 162-176, jul.-dez. 2019. 